
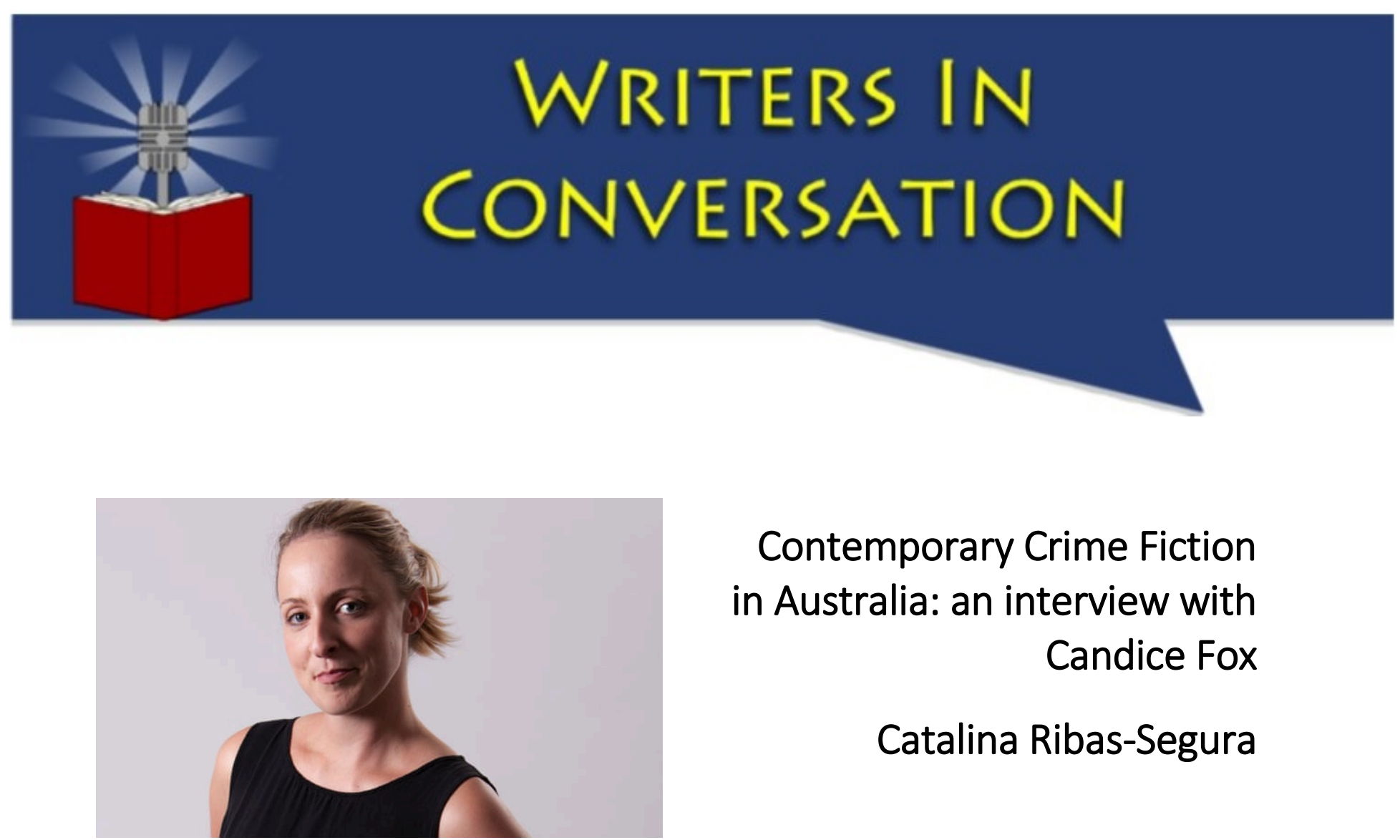

\title{
Contemporary Crime Fiction in Australia: an interview with Candice Fox
}

\author{
Catalina Ribas-Segura
}

Australian author Candice Fox has become a relevant name in the genre of crime fiction in Australia since the publication of her first novel, Hades, in 2013. In six years, she has authored two trilogies: the Archer-Bennet series (2013-2015) (Hades, Eden and Fall) and the Ted and Amanda series (2016-2018) (Crimson Lake, Redemption Point and Gone by Midnight) and coauthored a novella and five novels with bestselling American author James Patterson: the Harriet Blue saga (2016-2019)(the novella Black and Blue and the novels Never Never, Fifty Fifty, Liar Liar and Hush Hush) and The Inn (to be published on 6 August 2019).

Candice Fox is not only prolific but her works are also widely recognised. Her first novel, Hades, won the most prestigious Australian literary award for crime writing, given by the Crime Writers Association of Australia: the 2014 Ned Kelly Award for Best Debut Novel; her second novel, Eden, received the 2015 Ned Kelly Award for Best Novel; and Fall, Crimson Lake and Redemption Point were shortlisted for the Ned Kelly Awards in 2016, 2017 and 2018, respectively. Her works have also been accredited by the Sisters in Crime Association, which gives the Davitt Awards for the best crime books written by female Australian authors. All of Candice's books have been shortlisted for Davitt Awards.

Furthermore, her collaboration with James Patterson has also been fruitful as their first novel together, Never Never, reached the number 1 position in the hardcover and combined print and e-book categories in the New York Times best sellers in the first week after its publication and the novel was a bestseller in Australia and the United Kingdom.

Fox, whose first novel took almost a decade to be published, manages to work on two novels at a time: while she writes one, she thinks about the second one; when she edits the first one, she writes the second one, and she spends six months in each phase. Furthermore, Fox taught Creative Writing at the University of Notre Dame (Sydney) and began a PhD thesis in terrorism and literary censorship, which she has postponed to maintain the publication requirements on her. 
Her writings, set in Australia, examine current ills in present society: from abuse of power, violence against adults, children and animals to unhealthy family relations, the abuse of corporations and lobbies or the internet as a tool that paedophiles use to contact their victims. In her novels, Fox forces her readers to question their thoughts on these issues, on how to approach them and deal with them.

I read Candice Fox's trilogy as part of a research project titled 'Postcolonial Crime Fiction: A Global Window to Social Realities' (POCRIF) ${ }^{1}$, financed by the Spanish Ministry of Economy and Competitiveness. I loved the trilogy and, as part of the activities to bring research closer to the wide public, the members of the research project presented the novels we studied and our works in different bookshops in Palma de Mallorca and Barcelona (Spain). Her only novel available in Spanish was Hades, so I focused on that one and I explained some comments of the audience to Candice. In the interview, we talked about her experiences as a professional writer, she gave me insights into the genre of crime fiction and, although she had published Crimson Lake and the novella Black and Blue, with James Patterson, we explored her first trilogy: Hades (2013), Eden (2014) and Fall (2015).

This interview took place via Skype while Candice Fox and I were at our respective homes in Australia and Spain, on 18-19 October 2016. Candice was friendly, approachable, generous and willing to answer all the questions I had for her.

CRS: In my opinion, the novel Hades (2013) focuses more on the character of Eden and the novel Eden (2014), on the character of Hades. Why do these novels have these titles in this order and not the reversal?

CF: The original title of Hades was going to be Dark Creatures. When I took it to the publishers they said Dark Creatures referred to sanctity so they actually came up with the trial Hades. I hadn't written another book and I didn't know if I was going to write another book or not, or of it was going to be any good or anything like that. I only had one publishing contract, so it was a bit of an accident.

When I wrote Eden, I wanted to call it Winter Days but they said: 'Well, we've got Hades and it's just one-word title and maybe we'll make like a gimmick one-word titles Hades-Eden.' Then I came up with Fall, because there was really nowhere else to go at that point. We couldn't call it Frank. Titles are very, very hard.

For my next one, Crimson Lake, they said: 'What do you want to call it?' I gave them sixty titles and they rejected them all. I gave them twenty more and they rejected them all again. And then Gaby [my agent] came up with the title Crimson Lake. I don't really mind what is finally called, really. It's sort of a marketing decision. People will say to you: 'That sounds sci-fi,' and I didn't even know it sounds like sci-fi! Titles are funny things. My friend Adrian McKinty is another crime writer, and he's calling his next book Police at the station and they don't look friendly. And his publisher said: 'You can't have a nine-word title. That's

\footnotetext{
${ }^{1}$ The website of the research group can be accessed in the following link https://crimefiction.net/. The author would like to acknowledge the support provided by the Spanish Ministry of Economy and Competitiveness for the writing of this article (Research Project FFI2013-45101-P).
} 
too many words for a title.' In the end he said that's what he wants to call it and that's what he's calling it.

CRS: But that's nice. If he's allowed to have that title, then that's nice.

CF: Yes, it's nice. If I went to my publisher and I said I want to call it this, and she said no, I would say: 'ok'. I can't argue with mine: my publishers are way too nice. So I do what they say.

CRS: In the debate that we had regarding titles, we never thought they were the publishers' ideas. We thought they had mythological/ biblical references.

CF: I was going for that when I named Hades and Eden the characters. And that's what I was going for with Fall: I thought like the fall of men, to be attracted to that final. I needed a oneword title. You would be surprised to know how much publishers influence a book. For the first draft of Hades, I didn't have Jason Beck's perspective in there and they said: 'We don't know much about this killer. Can you add in all these different parts?' So a lot of times they influence the story. At the moment I am writing novels and I have so many people who are relying on it: I have my UK and my American publishers and in Australia as well, and then I have got James Patterson's people. So whenever I'm writing, and I am coming up with ideas, I have so many people who want to know what I'm doing before I've done it, because they don't want me to wait a whole year on a book and then reject the idea. They want to know that idea all the way through. So when I am starting to write a novel now, my publishers would say: 'Oh, watch it out!' And I'll say: 'This person killed this person for this reason.' Then they say: 'We like that', or 'Could it be this?', 'Maybe you could change it like this?' There's a lot of influence from publishers that people don't know about in all that.

CRS: Regarding the covers of the novels, those published by Kensington Fiction present an eye and either an object or a hand in its forefront. Those by Penguin show birds, the skeleton of a tree and leaves as well as a combination of different colours (white and blue, blue and black and black and red). Other covers of your novels translated into other languages, such as Hades published in Spanish by Pàmies or in German by Suhrkamp, show a man flanked by a boy and a girl on top of a mountain of rubbish looking ahead, with their backs to the readers, and pose them a question. Do you have a say in the selection of the covers? Are they chosen according to the marketing knowledge about readers in specific countries or continents? Do they depend on the marketing in specific countries or continents even?

CF: This one we are going for we were going on a trend, I suppose. Different countries do different things, I suppose. The German one was originally the Australian cover. This is the Japanese cover and it's a bridge, the Harbour Bridge. They also changed the title and it has Hades on it but in here there is a Japanese word for reunion, coming back together. So it's interesting, all the different covers. Sometimes they asked me what I think and sometimes they don't. When they did the American cover of Hades, I basically said to them: 'I hate that', and they said: 'Oh, we don't care'. I hated the American cover because it didn't make sense. All it had to me was a Middle Eastern girl face, a piece of barbed wire and a little butterfly, I 
thought it didn't relate with the content. It looked like a memoir, an asylum seeker, a refugee. Particularly, why is the barbed wire? behind the barbed wire? They are not going to see any Middle Eastern characters. It's not a bad cover, but it tells a different story to the story I am telling. My Australian publishers are really great with the covers. They show me their concept and then they show me the colours and follow my suggestions.

CRS: The character of Eden Archer is depicted as a superwoman: she is beautiful, intelligent, strong and active, but her main fears seem to be about interpersonal relations. Could this be due to her secret? Can Eden overcome this fear?

CF: I think that, maybe, a little bit of that social interaction fear comes from me. I think I am a little bit awkward and I tend to overthink social interactions. Being at a social party, I wonder: 'What are we going to talk about? What am I going to talk about? What if I say the wrong thing? And all these people! And what are they going to think of me?' It wasn't hard for me to get into that way of thinking. I think what I'm really trying to say is that Eden is a psychopath. She doesn't think the way other people think. Psychopaths and sociopaths have a lot of problems with empathy, so it is difficult for them to get on with people because they can't think 'what is that person thinking?', and 'what would make them happy?' and 'I could try to make them happy'. I've done a lot of research on psychopaths and they are very insular and concerned with what they want and what they need and it is a real effort for psychopaths to try and think out what other people want and need. I don't think she's unteachable though, because you see that she does progress across the three books. She doesn't long to be that, she's just being that, she is definitely trying to change. You can see her doing things like going over to Frank's apartment and painting his apartment for him. That was an interesting gesture because in one way it's arrogant to say: 'You should do it yellow. I'Il just do it. I'll do this half yellow' and you can see that he wanted it blue. But in another way she's trying to say: 'I am helping you and trying to make you happy.' So it is a confused gesture, really to get it right. That's where I was going to with the character.

I wish now I hadn't made her so good-looking because I think that if the character is athletic and stunningly good-looking and really super intelligent, she's obviously got a lot of money and she's very talented, it starts to get unreal. So in Never Never, Harriet is really tough and she's got this vulnerable background but I made sure that she's not very glamorous, she is short, she's got short hair, she's a bit daggy in her clothes and everything. I think Eden looks a bit too perfect. I've tried to scar her up a little bit, she's got scars and things now.

CRS: Indeed, she does have many, especially after the second novel ... Regarding the character of Frank Bennett, he follows the stereotype of the hard-boiled detective (he feels lonely and a failure, turns to alcohol to forget his traumas, and cannot have long-lasting relationships with women), but he is not a brute. When creating your characters, are you influenced by other authors or detectives?

CF: I do think so. Hades was the first crime novel I ever wrote. I wrote four novels before Hades and they all were rejected, but none of them were crime. So it was my first try and I think I needed to start from a safe place. I knew about this cliché hard-boiled detective, and 
that was my starting point for Frank. I didn't put so much effort into Frank because he was just the lens through which to view everything else, so I didn't want to work too hard to try to understand him. I thought I would use something familiar for people, that they would be able to relax into that voice. But l've certainly changed now. I'm leaving those sorts of things behind ... I'm writing female protagonists now. And then my protagonist in Crimson Lake is a man as well and he does a bit of drinking but he's a lot more gentle. I also think Frank might have reflected the kind of guys that I was hanging around at that time. My ex-husband was a lot like Frank, a smart alec, a womaniser. My husband Tim is a lot more gentle so now my male protagonists are ending up a little but like that. It happens for different reasons. People like my new detective, Ted, because he is more gentle, and people like Frank because he is familiar.

CRS: Most female characters in the trilogy have no children, and male characters are the ones who behave like fathers. Could you share your thoughts on motherhood and female detectives?

CF: I think you've got to be careful and not making them female for a reason like you try to prove a point. There are certain writers who you can tell have made a female deliberately and everything is 'because I'm a woman, I am a better crime fighter' and all this sort of thing. I think the character should be as good if it's a woman or if it's a man. It shouldn't really be because she's a woman, she's a better character or because he's a man, he is a better character, because that's all you want really: you want equality of the characters.

It's hard when you have to put romance in it. Like with the James Patterson's books, you have to have some kind of love interest, so I've got this female character, Harry, but in every single book she has to, at least, flirt with somebody or have some kind of love interest happening. I don't know how to write about that stuff really. I had one friend say back to me: 'If Frank and Eden ever get together, I'll never read your books ever again.' I'll make a note of that. I certainly wouldn't put Frank and Eden together, they would not, it would not be right.

CRS: What is your opinion on alternative families and the genre of crime fiction? In Hades, for example, he becomes the father of those kids, Eric and Eden, so that's a way of an alternative family, because, definitely, he does not adopt them, he thought they were dead but he took care of them. Do you think the genre of crime fiction is a good one to explore these other ways of existing and of living and how it happens?

CF: That's interesting. You know, my mother has four of us and I'm the youngest of her children. Then, she adopted two more and then she fostered kids all the way through my childhood. She would have four or five or six more, sometimes, at a time. So it was a weird way to grow up but it was good, it was character building and that sort of thing. You know, I'm sure I would have also enjoyed a more normal childhood. Just this thing that it has been built in me having a weird family like that has made me stronger and I've used alternative families to make my characters stronger, so Eden and Eric have lost their parents and they have got this sort of foul spirit in them.

I think it's hard to have a character that you really respect when their parents are around because you've got the hero and they are strong and you admire them, and then if 
they've got a dad telling them what to do or someone's mum they have to go and visit or say, 'I'll call you, mum!'... It's often good to remove the parents. So I'm writing about Harriet Blue right now for Never Never. Her mother is a drug addict so she is calling Harriet and asking for money and saying 'I cannot live with you' and this sort of thing. Her mother is almost a child to her. I'm exploring that at the moment. I think not having a normal family myself made me stray away from exploring normal families.

CRS: In Eden, when you get to know Hades' childhood, there's so much violence and that's another alternative family he lives with.

CF: A lot of people were really disturbed by the dog fight. I didn't think people would be so disturbed by that. Surely if you can get through Hades, and all the kids having their body parts chopped out, surely people will be OK reading the dog fight, but lots of people told me they couldn't read the dog fight.

CRS: I read it, but I had to take a 30-minute break before I could continue reading. I thought it was so cruel of that man to throw Hades to the dogs! Such a level of cruelty blew my mind ... It was difficult to continue reading after that. The way you described the whole situation was so visual and real ...

CF: That's the perfect example of the psychopath, because he doesn't think about whether the boy will live or die, just that it will be fun. Psychopaths are very impulsive and they think about what will amuse them at that time, they do not think about what's going to happen tomorrow. In the end they just think this will be funny. I find the figure of the psychopath so interesting, just how they can live like that. It's so interesting.
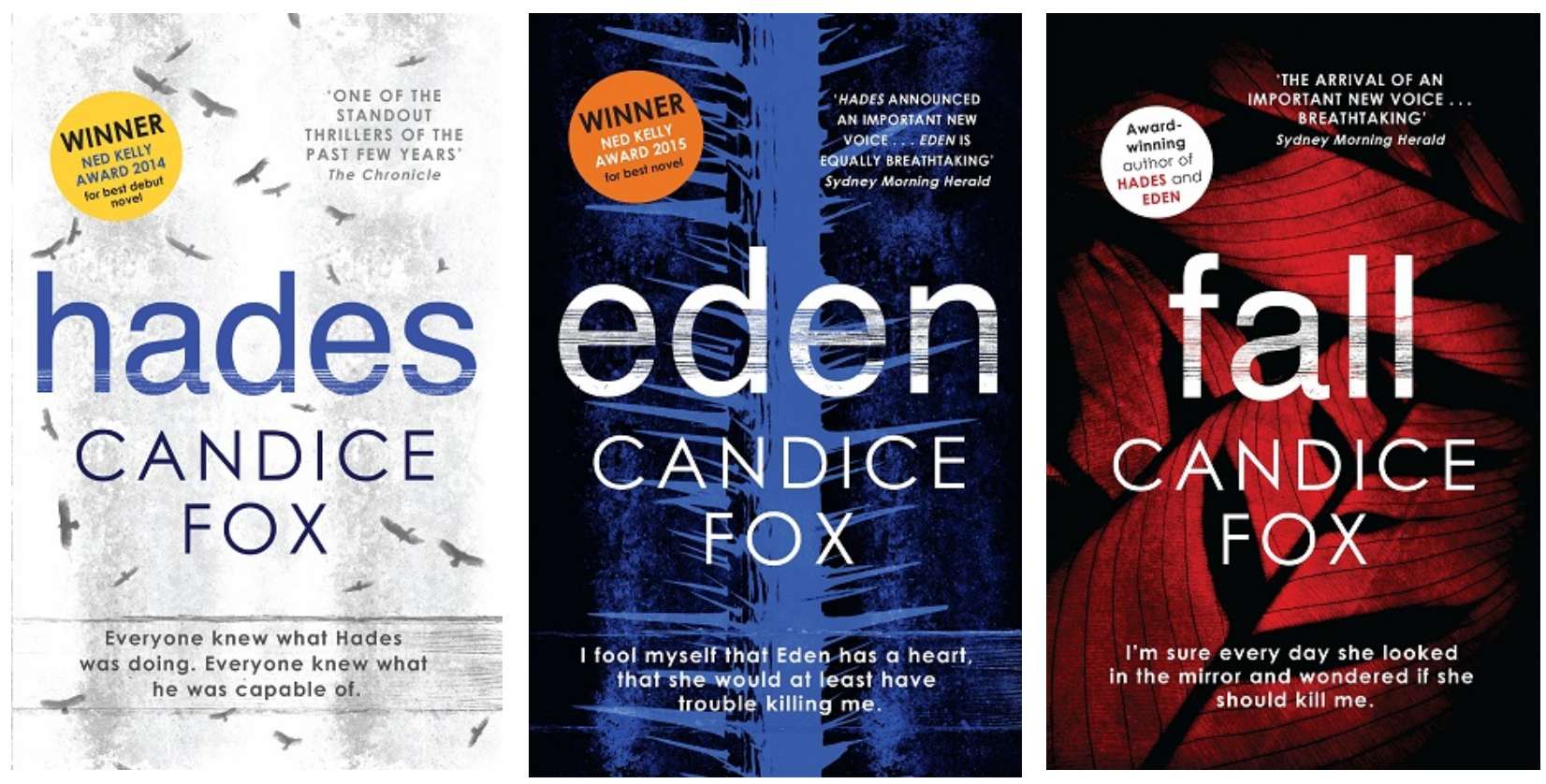

CRS: Which social issues do you want to address in this trilogy? For example, in my opinion, Hades presents some moral dilemmas and decisions made by the characters, many regarding 
health issues and family relations, which may shock many readers. In Eden, Eden goes to a farm in order to fulfil her investigation and their interpersonal relations are also questioned. Meanwhile, Hades is trying to solve a mystery from his brutal childhood and youth: the disappearance of an Indigenous Australian female friend. There are so many social issues in the novels. Which issues did you want to explore more?

CF: I think that in the best crime fiction, you can get a snapshot of the society and pull it and it's real. The things that people learn and enjoy when reading Charles Dickens ... He had real people in there that you could recognise, like he had prostitutes. That's exactly what they are like and no one wrote about. If you bother writing it, it would have to be a glorious story about really important people, whereas Dickens talks about scumbags and prostitutes, prisoners and as people really were.

I try to do little snapshots of what is happening in society, so people can say l've seen that, I know that. I've been out there to Camden and the people like that are really closeminded. Everybody lives on the farms. Their world is so small they cannot even imagine going to the city and hanging out in the city for a night because they just wouldn't belong, and that's the thing: their world is so tiny. It is because l've known people like that, l've been out there myself and I've seen how they live. I think it has to be true and possible. I do believe in my little agenda every now and then, for example, how people would be. You know like in social media something happens. Like the Nigerian girls who were abducted, for example. Everybody in the social media goes: 'It's terrible', 'I'm so sad', 'How bad that is!' and then 'Ok, I'm going to work' and they forget about it. How people say they are so sad, but it's all really fake.

I just try to critique things that I see. I think that if you are a good writer, most of the times you are sitting around watching and analysing what people around you are doing and thinking. When I'm on Facebook, l'm watching what everybody is talking about and I'm judging a little bit, I guess, just quietly. The only way that I can explore those things is through my fiction, I suppose. I put people in there that I get frustrated with as well. I call them 'tourists' and things like that. The character of Penelope, Sky's mum, is a combination of middle-aged women that I've known that I hate. And Eric is the pompous guy with the tattoos and the nice shirt, like all those guys that I ever encountered and I put them all together in one character.

CRS: Could you talk more about the different worlds that appear in the novels (rural, urban, central, peripheral, present, past ...)?

CF: I've moved around a lot in my life. I grew up in Bankstown, which is in the Western suburbs of Sydney, and so I had that sort of urban life. It was getting a bit rough for us, so my mother moved up to the Central Coast of New South Wales, and suddenly I went and became this beachy person: lots of surfers, we had surfing classes within school ... I lived there for a couple of years and then I moved into the city, right in the middle of the city and I was working at a hotel in the CBD. Then I joined the Navy for a couple of years, and I was sailing around and frequenting King's Cross. Then I moved to Queensland. So I had all these different landscapes as part of my life. I've adapted to the culture very well in each of those environments. 
I like to explore different settings in that way because l've known so many of them and I think of different stories that would fit in different environments. But I always feel that thing where I have the present and the past, there is like the present and an alternate present. I think having just one present all the time makes it difficult to create the tension, so I try to have the present and then get to a point where you think: 'I don't want to leave it', but you build up the tension, build it, build it and then you leave, and you go somewhere else, and then you build up the tension, build it up and then you have to leave and come back here. It's that tension building, that exercise that keeps people turning their pages over, especially if you leave just when you don't want them to leave, you leave right on the edge of something and you go to that other place and ... So I always do that. I think I would get bored if I was just in one place and one time. Even in books which are all one place-one time, the character goes back and remembers. Like, for example, in my next one [Redemption Point], he remembers being in prison, so it's in the present but you just have that little detour where you go and you think about when he was in prison, then he comes back, then he goes away for a while, then he comes back and then he remembers his childhood. So there are these little detour options to keep it fresh.

\section{CRS: What kind of readership do you have in mind?}

CF: My actual readership is middle-aged to older ladies and they make up the bulk of who reads my books. Every time that I do a writer's talk, ninety per cent are ladies from about $\mathbf{4 0}$ years old to about 60 . I do not really try to think about that when I write. My reader is very faceless. I think: 'What are they going to think is going to happen next?' I think a lot about my publishers and my agent. They are both ladies in their 50s and I think of what they would like to see and what would excite them. And I ask them sometimes what they think is going to happen next and who they think the killer is and, if they guess it, then I have to change it, so they would not be able to guess. But I do not keep a specific reader in mind. I do not want to write to them, I want to write to me, I want it to be interesting to me, because I'm the one who has to plan and go through it so I do not want to bore myself.

\section{CRS: Could these novels be set somewhere else or could they just happen in Sydney?}

CF: Actually, when I sold the TV rights to Hades, I sold them to a woman. She's had them for a couple of years and has done nothing with them. When I met her for the first time, she said she thought it would go well in an Asian market, in an Asian city. I said: 'What?' Maybe, the city harbour instead of being the Sydney harbour could be of Tokyo, in the ocean, and Hades could be an old yakuza boss who retired and the cast could be all Japanese. Literally it is possible, but I think that Hades, Eden and Eric are global characters and they could be any race, really. But Frank is so Australian, he would have to change the most because he is so knock-about Aussie, he is an Aussie bloke, in my mind anyway. I think there are a lot of things he would have to change in the way he sees and the way he attracts women. I think the rest can be translated into other countries. As long as it is dark and noir, I think you can apply noir to all the different races and countries, and that would be fine. I would not be sad it if went to another country as long as there was quality. 
CRS: Would you consider adapting your texts to the screen as films, TV series or as videogames?

CF: Videogames, that would be weird! I'd love to see it on the screen: I think it would be amazing. I thought about different actors I would like to play different people, but I don't have lot of faith that it will happen because it's so difficult to get things made in the TV. There's not a lot of funding around, particularly, in Australia. I sold the rights to Hades and Eden to a woman who hasn't done anything with them. I sold the rights to Crimson Lake, my next one, only after $\mathbf{5 0 , 0 0 0}$ words, which is amazing because I said to the people: 'You do not even know how it ends', and they said: 'Ah, we don't care. We just want it before anyone else gets it.' So they have hired a writer and they are pitching the TV series to the ABC. I never hear anything happening so I do not think much about it because I do not want to get disappointed if it never happens in the end.

CRS: Have you considered writing spin-offs, prequels or sequels?

CF: I was writing a book about Hooky [a character in Fall], so it was a sort of a spin off. I wrote half way through that but my publisher told me to stop. I couldn't delay because Crimson Lake is very popular around all the different publishers. They've called me from England and it's shopping to Random House in the US. She didn't want me to get all these new fans from Crimson Lake and then the next book be a book 4, so they have to go back all the way to Hades.

I have thought about that. Somebody said to me they really loved all the stuff with Hades back in the 1960s in King's Cross. I thought about writing a prequel, only about Hades in King's Cross being a crime overlord and after Bear dies and after Sunday goes missing, but I have to keep pushing forward and doing what my publishers want me to do. This is only my fourth year, it's my early career. I am trying to build up my relationship with all the different publishers so basically I do what they say, really.

CRS: You have also published two books with acclaimed author James Patterson: Black and Blue (2015) and Never Never (2016). Could you explain the process of co-writing a book with an author you admire? You said that James Patterson planned every chapter before starting to write. But, how is it working with someone you admire? Do you get the chance to criticise or you don't dare?

CF: He is really good. Working with him has been great because I thought he was going to tell me what I had to do and this is it, he'd outline what I have to do and I'd have to do what he says. I was trying to come out with a name for Harriet, and I finally had it: Harriet Blue. It's such a cool name! 'I'm going to ask if we can call her Harriet,' I said. And people replied: 'What if he wants to call her Gladys or something else? Because then it changes the whole thing and you'll just have to suck it up and do what he says.' All the things I have suggested he's been totally happy to accept to add. He's really great. We put that outline together. When I was writing Never Never, I got half-way through and I thought: 'This will be better. We'll go and do this and then we'll go back to the outline.' He was totally fine. He was really open to my ideas. 
It's good working with somebody because we are both responsible for the book. So, if it's going great and everyone is loving it, then we both share that; but if everything went wrong, then it would both our fault.

CRS: I wonder if you could you talk about other authors you admire, about any genre, not just crime fiction.

CF: Australian author Peter Temple: he really is why I do crime, really. I read Truth which won the Miles Franklin award. He's won like five Ned Kelly Awards. His male characters were so real and the way they talked is the way I heard men talk to each other. The dialogue was just spectacular, so real. After reading Peter Temple, I went back to my own work and started cutting men's dialogue in half: it has to be short and economical and punchy. He just taught me things. His work is fantastic. His book The Broken Shore was just stunning. It had two puddles in it and the dogs in that book were real: you could see them, you could see the way they moved. I really admire him. He's not writing anymore, which is sad. I think he's just too old. He's got the royalties that come out from his books so I suppose he doesn't need the money anymore. ${ }^{2}$

I've met a lot of crime writers going around different festivals. I really like Adrian McKinty. He has written a series of books about a detective in Northern Ireland during the Troubles, the civil war. His character is really good. He is very good for unpredictable things. His character is a bit bohemian, cheeky, it's like Adrian himself, really. But every now and then his work takes a completely new angle and it's like: 'wow, I did not see that happening.' He's very good for surprises: he is a surprising writer.

I read a lot of true crime when I get the chance because it's not hard to read, it's very straight forward and I don't end up picking up the voice. Sometimes I'll accidentally pick up the voice of other writers when I'm writing. So that's where I'm spending a lot of my time. I like Lee Child and his Jack Reacher character, because he has got a very distinct voice. Jack Reacher is very good: he is military. Just being able to maintain that very distinct voice over twenty novels is very hard. I really admire that.

\section{CRS: You have achieved many dreams these last years. What else would you like to achieve?}

CF: I never really dreamt of having so many books out. My big dream was just to have one book published at all. I almost got Hades published on the Isle of Man. I was going to have 100 books published there, I was going to pay this man, I was going to have $\mathbf{3 0}$ copies here in Australia and I was going to hand them out to my friends and family, and that was so huge a dream! And I had never thought that would happen, so I was celebrating, it felt so amazing. But he ran out of money and I was just crushed. So I never thought I would get a book published with Random House in Australia because they were just too big and it was just too hard. A friend was working at Harper Collins in Australia and I asked her: 'How many new authors do they take every year?' And she told me: 'We get about 5000 submissions and we take about 11 new authors in every genre.' So I thought: 'That's not going to happen to me'.

\footnotetext{
2 Peter Temple died in March 2018
} 
So when Hades got published, it was beyond. I'd never imagined about writing another book and getting another book published, because it would be like double, and then it happened! And then I was winning awards! I don't really have any publishing dreams anymore because I cannot imagine it getting any better than it is right now. TV deals and movie deals, seeing it on the big screen, I can't imagine that because it feels like l'd be greedy, like having too many of my dreams coming true. Some people never even get one book published: it's so hard. I know a lady who is $\mathbf{5 0}$ and she's been trying to get published since she was $\mathbf{2 0}$, and she cannot get a book published. And I got books over here and books over there. So I feel a bit greedy sometimes.

Really what I want in my life in the next few years is that my husband and I are going to try to have a baby. We only rented this apartment so l'd really like in the next few years to buy a nice house in a place we like, for my husband to be happy and this sort of thing. I think it's more of a life thing. When it comes to writing, it'll just like to write for as long as I can and keep being published for as long as I can. I don't take it for granted because I think it could all fall about at any moment. I get anxious about that. If that happened I guess, I'd just go and teach English again. Being a writer is hard but it's really great. It's an amazing thing to do for a living: writing stories and thinking about them. It's given me permission to be exactly who I am. At high school I was a bit strange and not very popular. I used to read a lot of crime stories and write about crime, people thought I was a freak. Now that's what I do for a living! I feel like the ugly duckling now has become the nice swan and it's like: 'Ah, you were a swan all the time!'

\section{CRS: What do you think your contribution to crime fiction is?}

CF: I'd like to think that I'm writing Australian noir. I'm not sure there's been an Australian crime fiction that is steamy and mysterious and really dark. I think that when I write about Sydney in particular in crime fiction. Sydney is always beautiful and sunny and the glittering Sydney Harbour and the beautiful Opera House and it's always so lovely. I wanted to imagine a Sydney that was dirty and gloomy and industrial and I hope that is different. And I also hope there is something almost Gothic, just a little edge of supernatural to it that is different, because particularly Hades is tipped with all the animal sculptures and the truck going by and the steaming and smoking. It's a little bit Tim Burton and supernatural, just the tiniest flavour of that, not too much of it. I hope that gives me a difference.

I really like Jeff Lindsay's Dexter series. There's a little part of me that wanted to do a Dexter-like series in Australia, a sort of dark hero. It's like the story of a psychopath and the psychopath is the hero but there's a little bit of dark humour and a little bit of creepiness in it.

CRS: In Australia, there are many writers' festivals, where authors and readers exchange ideas, opinions and feedback. Do they provide you with food for thought for your writing?

CF: Not for my writing practice so much, but the good thing about writers' festivals is that I meet other writers, because this is such a lonely job. I do not have any colleagues. My husband gets back home and I'm whinging about my job, he doesn't really understand because he's not a writer and I cannot whinge online because you cannot say: 'Oh, I went to 
sign a contract at the office and it was not ready yet, and that's really annoying' because all the other writers would say: 'I'd really like to sign a contract.' You can't really whinge. And you can't really ask some questions to other writers: 'What happens when you get a movie deal and this?' and they say: 'I never had a movie deal.' At festivals, I can find other writers and figure out at what level they are at and ask them different things, especially writers in other genres because if you are a crime writer and someone else is a crime writer in a way you are in a competition with each other. So I know romance writers and fantasy writers and we can ask each other questions without feeling that we should be jealous of each other.

Writer festivals are also really great for meeting the readers and seeing what they think. I am totally shocked because Frank is everybody's least favourite character. Frank's my favourite! Frank is me. How can he not be your favourite? Everybody says Hades is their favourite and I am: 'Really?' I felt really shocked about that. It's only by interacting with readers that I learn all that. I ask them: 'Why? Why do you like him so much?' I can really analyse what people enjoy and then make sure that they have more of that, and learn as a writer.

CRS: It's quite similar to the process of writing a PhD thesis, in the sense you can't really whinge with anyone because you have to figure out the solutions to your difficulties ...

CF: It's the little things. When I'm home by myself, it can get a little bit lonely. I can call my mum and I chat with her for a while. My publicist was telling me that, where she used to work in the morning, all the girls in her little section had a coffee together and they talked about the TV shows of the night before. And I was like: 'Can I skype into that?' I'd like to have my coffee and a morning TV-meeting, but I don't have anyone to do it with.

CRS: This is what happened to me doing my PhD: it felt so lonely. It's hard, but it's part of the process. I think it's good because many people don't know how to be on their own.

CF: Most people cannot work unless there's somebody watching them. I like sitting here all day and being my own boss.

Two years later, Candice continues to write and be published and has toured Australia, Europe and the USA. Moreover, her dreams have come true: she has bought a house with her husband and has become a mum.

Catalina Ribas-Segura is an Australian and Postcolonial Studies scholar. She is member of the Australian and Transnational Studies Centre at the University of Barcelona (Spain) and teaches English for different purposes at CESAG-Comillas Pontifical University (Mallorca, Spain). 